tion which is in most cases all that appears, he seems to me to be guilty of a genuine Irish bull! That there is any doubt of the existence of images of other sense departments than visual, auditory and motor, I cannot accept for a moment. When Dr. Slaughter says that 'the real existence of these images is doubtful,' I understand him to mean their existence in other minds as well as in those of his subjects. He intimates as much when he, says that 'our subjects failed to manifest such an elaborate equipment' (as the tactile, gustatory, olfactory, thermal, pain and organic imagery mentioned in my monograph), apparently throwing discredit on the truthfulness of my report of my own images. He says: 'One general question bearing upon the work' is 'whether the images obtained under introspective conditions are the same as the normal images of every-day life.' I can not conceive that the normal images can be studied in any other way save in ' introspective conditions,' and it is only in moments of voluntary or involuntary introspectiveness that we become aware that there are any ' normal working images' at all. So that there is no question as to the sameness of the images. The vital question is whether in subjecting or in trying to subject the flow of images to the control of scientific experiment we may not be changing the nature of these images. I believe that we can not change their sense quality. They remain constant in quality, but the machinery of scientific research may cause them to be obscured or driven below the threshold.

NHW YORE CTrX.

WILFRID LAY.

\title{
ON LAUGHTER.'
}

A friend of mine once spoke of Sully's writings as sane, eminently sane, but dry. In this 'Essay on Laughter,' however, the reader is fairly deluged and swamped with lively adjectives and figures of speech. 'Blithely' tumbles merrily after 'sprightly' on every page, and 'floods of merriment' chase wildly the 'rillets of joy' of less significant dimensions. Irrelevances in conversation, we are informed, are among 'the recognized tributaries of the river of laughter,' and over all the imp of laughter shrieks his way with uncontrollable joy. Therefore we may say sane, eminently sane, but not dry.

This beautiful largesse of adjectives has, however, also a woful aspect. In the modern world of commerce a business manager would hardly accept a report spread out over 450 pages, a report which might easily have been compressed within roo pages. I see no reason why the

${ }^{2}$ James Sully, 'An Essay on Laughter, its Forms, its Causes, its Development and its Value,' Longmans, Green \& Co., New York, Ig02, pp. 44I. 
psychologic public should not be treated in the same concise, businesslike manner as is the head of any ordinary business firm or manufactur-

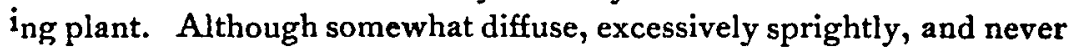
deeply original, still Sully's treatment of the subject is by far the best yet published. It is therefore with diffidence and with deference that a few remarks on the subject are here ventured.

So far as ticklishness is concerned, a very important factor in the production of this feeling is undoubtedly that of the summation of stimuli. In a research of Stirling's carried on under Ludwig's direction ${ }^{1}$ it was shown that reflex contractions only occur from repeated shocks to the nerve centers-that is, through summation of successive stimuli.

That this result is also due in some degree to an alternating increase in the sensibility of the various areas in question from altered supply of blood is reasonably certain. The connection of tickling with capillary pulsation is therefore worthy of investigation. As a consequence of this summation-process there could result in many cases and in cases of excessive nervous discharge the opposite of pleasure, namely, pain. This would result from long-continued stimulation or from light stimulation whenever the central nerve cells were possessed of little stability or inhibitory capacity, as in sickness, etc. A number of instances have been recorded of death resulting from tickling and there is no reason to doubt the truth of the statement that Simon de Montfort, during the persecution of the Albigenses, put some of them to death by tickling the soles of their feet with a feather. Mediæval justice and the hidden doings of the Inquisition might reveal many such instances if they were investigated. Lauder Brunton suggests that possibly the different effect of a slight stimulus like the touch of a feather, which causes intense reflex action, and of a gentle but steady pressure of the finger, which gives rise to no reflex action at all, may be due to the stimulation by the latter of two sets of nerves which counteract or inhibit each other." It may be that the effect of steady pressure may cause a general diffused hyperæmia, whereas the stimulation resulting in the phenomena of tickling may and undoubtedly does cause a sudden convulsive hyperæmia which entails an explosive motor discharge. This relief of sudden congestion by additional stimulation of other and different nerve endings is observable in the relief afforded by rubbing or stroking a part which has been pinched or bruised, or by scratching an itching spot.

'Stirling, Ludwig's Arbeiten, gter Jahrgang, p. 290; Sitz. Ber. d. k. Säch. Gesell. d. Wiss., Bd. XXVI., p. 439.

'Isuder Brunton, 'On Inhibition,' 'West Riding Asylum Reports,' 1874, p. 179, and Nature, 1883, Vol. XXVII. 
An additional causal factor in the production of tickling may lie in the nature and structure of the nervous process involved in perception in general. According to certain histological researches of recent years ${ }^{1}$ we know that between the sense organs and the central nervous system there exist closely connected chains of conductors or neurons, along which an impression received by a single sensory cell on the periphery is propagated avalanche-like through an increasing number of neurons until the brain is reached. If on the periphery a single cell is excited, the avalanche-like process continues until finally hundreds or thousands of nerve cells in the cortex are aroused to considerable activity. Golgi, Ramon y Cajal, Koelliker, Held, Retzius and others have demonstrated the histological basis of this law for vision, hearing and smell, and we may safely assume from the phenomena of tickling that the sense of touch is not lacking in a similar arrangement. The importance of this law, it may be incidentally remarked, is manifest at a glance, for a future science of education. The spread of all methods whereby first-hand information is gained, while empirically found to be eminently satisfactory, is now known to rest upon a scientific basis. The laboratory method, kindergarten and primary object lessons, and constructive work, the use of illustrations in textbooks, magazines and newspapers, the stereopticon, etc., etc., may be cited as empirical recognition of this scientific fact.

May not a suggestion be offered with some plausibility, that even in ideal or representative tickling, where tickling results, say, from some one pointing a finger at the ticklish places, this avalanche-like process may be incited from central centers, thus producing, although in a modified degree, the pleasant phenomena in question? It would be in such a case another form of circular reaction.

Among the parts not mentioned by Sully as subject to ticklishness might also be mentioned the palate and the lips or any part rendered more or less sensitive, as in the case of sores. The palate, in many cases at least, may be tickled by having the tip of the tongue pass lightly backwards or forwards over its surface. In certain physical moods such ticklishness with me is almost unbearable. The reactions observable upon the recovery by a limb of its normal condition after having been 'asleep' are identical in some respects with certain phenomena of tickling. A German child remarked in my hearing that champagne 'schmeckte ebenso wie eingeschlafene Fïsse.'

' Ramon y Cajal, 'Einige Hypothesen "ber den auatomischen Mechanismus der Ideenbildung, der Association und der Anfmerksamkeit,' Archiv fïr Anatomie und Entwickelungsgeschichte, Jahrgang 1895, pp. 367 ff. 
In visual and auditory perception there may be induced some of the phenomena of tickling. A medical friend of mind informs me that certain notes in deep solemn music affect his epigastric muscles in a sort of shock reaction. The quivering can be induced by false notes at times. As to the deepest causal factor, I should say that tickling is the result of vaso-motor shock. In addition to these cases the phenomena of tickling may be autogenous in nature, that is to say, vaso-motor changes may be induced in the skin without apparent external stimulation. These changes are known at times to produce the phenomena of tickling.

If hypotheses are in order, I might suggest that as the attitude of disgust and dislike may be an incipient act of vomiting or the rejection of unpalatable food, so the smile may betoken an attitude of the whole organism in which the inception of food is the most striking characteristic. These actions which are obviously so useful in matters of food may have become in the course of social evolution associated with other affairs because of their eminently social symbolic value. The lower animals must perforce express themselves somewhat differently because, according to the testimony of comparative anatomists ${ }^{1}$ they lack the necessary facial muscles for language and the smile.

The laugh may have another physiological raison d'etre besides that mentioned by Darwin, Spencer and Sully, of relief of cerebral distension and congestion. Like singing it may be a therapeutic agency in reference to pulmonary exercise, blood-oxygenation and general bodily nutrition. The deep inspirations which the singer and laugher are compelled to make cause a distension of a number of airvessels ordinarily in a condition of semi- or almost complete collapse. As a result of the laugh the circulation is hurried on through them and the lungs are developed to their fullest capacity. The well-developed lungs, by facilitating the process of oxygenation, favor the nutrition of the body in general. The laugh, it is true, causes ' a cessation of cerebral strain,' but the greatest relief is of pulmonary or vaso-motor origin. The sigh also possesses the same function, but the difference between the sigh and the laugh is the difference between work and play. As a general rule the play activities are more general and involve a greater amount of metabolism. The vitality of play is more intense. As singing has been recommended as a valuable adjunct in the treatment of anæmia and pithinoid chests, so laughter must not be denied its therapeutic and metabolic virtues. Deep inspirations favor

'Cited by A. H. Keane, 'Ethnology.' 
the flow of blood through the lungs, from the right to the left side of the heart. Thus occasional sighs or laughs, or in other words deep inspirations, interrupt the shallow breathing constituting so-called 'breathless attention.' The shallow breathing leads to stagnation of blood in the right heart, and an occasional deep inspiration is necessary to relieve this. By holding the breath for a moment the stagnation of the blood in the right heart will provoke epigastric pulsation and cause the veins in the head and neck to swell. In cases of death from suffocation or drowning, the right heart is found engorged with blood. Now in most instances of witticism or in joking, although not in all, there is an element of expectation, suspense or inhibited function. The laugh is the rehabilitation of function, the rebound to increased metabolism. This may also explain the easily-excited laugh of those attendants at a funeral or solemn ceremony where the grief is not too intense. Any foolish stimulus may cause the metabolic rebound. A friend of mine once attended an execution. The morning sun was excluded, the shadow and damp of prison walls were everywhere, the usual crowd of curiosity-mongers was present. Upon regaining the open air and sunlight the mujor part of the crowd burst out laughing with no other external stimulus than the exuberant sunlight.

The mechanics of laughter would also have to take into account the important influence exercised by the diaphragm, the inuscular walls of the stomach and glandular activity in the various degrees of the laugh.

Sully mentions the scratching of the head during a state of mental irritation as a well-known instance of the transference of expressive movements from one state of feeling to another, a la Darwin and Wundt. Lauder Brunton explains this habit of the English rustic and similar ones, such as pulling the mustache or beard, or the German habit of slapping the side of the nose with the finger, as a stimulation of some branches of the fifth nerve, thereby causing local dilatation of the cerebral vessels and an added ability to carry on a line of thought. In a similar manner the gustatory branches and the buccal branches of the fifth nerve are stimulated by taking something that has a strong taste, such as brandied cherries. In rural region's peppermint candy is the open sesame of wakefulness in this line. Sucking and chewing and sipping are stimulants greatly increasing the flow of blood through the carotids, as has been determined by experiment. Certain elements of the smoking habit have their raison d'être in activity of this sort. The habit many boys have of spitting on their hands and then of 
rubbing them together before taking a leap is based on the fact that thereby they obtain a sensori-muscular stimulation. Many mental and bodily automatisms usually explained by reference to some-general principles such as inhibition ought to be reëxamined with the view of ascertaining the special causation in question.

Some theories die hard. Of no topic in psychology is this more true than in that of the psychology of the comic. In Sully's 'Essay on Laughter', and in the article on this subject by Hall and the present writer, may be found in extenso a collection of such metaphysical hard-ridden and hard-pressed definitions. Nor are Sully and other modern writers altogether free from blame in this respect. Miss Calkins in her 'Introduction to Psychology' says that 'virtually all theories of the comic agree in defining the sense of humor as enjoyment of an unessential incongruity' (p. 284). Sully says, "The most promising way of bringing the several laughable qualities and aspects of things under one descriptive head would seem to be to say that they all illustrate a presentation of something in the nature of a defect, a failure to satisfy some standard requirement, as that of law or custom, provided that it is small enough to be viewed as a harmless plaything" (p. 139).

It is a Ptolemaic pastime trying to discover the causes and inner essence of laughter in the objective world, or even for that matter in the world of mental presentations. In the treatment of the emotions no scientific grounds for causal explanation or classification can be found in the objects of the emotions; no more can such be found for laughter, one of the prominent forms of emotion. The real causal ground of laughter is to be found in physiologic processes. A person may laugh when tickled, may laugh from the influence of drugs, may laugh automatically without the presence of mental presentations, may laugh as an exhibition of bien être, may laugh at a button on his coat, may laugh when there is only one single presentation in the mental field or when there are two or more. Moreover, these external things are not laughable in themselves. It is our reaction which clothes them with the cloak of humor, gayety, or what-not. In this the comic follows the general law of all emotions, including also under that term the field of æsthetics. These emotional judgments are revelations and judgments of our own selves and characters, rather than of the mountains, sculpture, paintings, or so-called laughable things. Thus the cockney's account of his exploit at a fire (quoted from the London Times) would hardly be yours or mine: " "Jump, yer silly fool!' we shouted, 'we've got a sheet!' and he did jump, and 
there weren't no bloomin' sheet, and he broke 'is bloomin' neck. Larf! I thought I sh'd 'ave died o' larfin'." That which is high tragedy to the gods in the gallery may be comedy to the parquet, and vice versk. "Avast thou wretch!" cries the demi-mondaine actress, "I would rather wear the filthy rags of poverty than don the imperial robes of sin." The artistic part of your nature laughs while your moral nature is full of pity ; meanwhile there is joy in the " nigger heaven' over another sinner repulsed.

Evidently the causal element lies in vaso-motor and nervous processes. The sense of joy present in the feeling of bien être, in the witticism, in the mild atmosphere of humor, is evidently due to vaso-motor phenomena and a discharge of surplus-stored energy where the discharge does not involve too much strain, effort or lesion. The laughter as a motor phenomenon may continue automatically, finally producing lesion and pain and in some cases death. In the more highly evolved form of this process, such as in wit, the element of suddenness is paramount, brought about by the coalescing of nervous currents seldom or never associated and by sudden vaso-motor and metabolic changes. In other words, we are dealing ultimately with mild forms of vaso-motor shock. Thus Dr. Edward E. Hale was taken when a boy to hear his father speak on a critical occasion. He was so impressed by hearing the orator cry: "Will any man dare say * * that he shouted from the gallery, "No, pa!" Neither of these elements taken by themselves are laughter-producing, neither can the ideas by themselves produce such a result, but the vaso-motor shock and sudden coalescence of nervous currents may excite by association the motor centers to intense activity. The same may be said of other such instances, as for example the following: A clerk in a book store upon being asked if he had William Watson's latest poem, 'The Eloping Angels.' "The Eloping Angels," he said, scratching his head; "No, I don't think so, but we have the sequel to it, "The Heavenly Twins." "

In other words, it is not an appeal to our sense of superiority, to our feeling for the ludicrous, to this feeling or to that; the enjoyment we call humor or wit is the result of vaso-motor and nervous changes. The objects of the humor or wit may be numberless, or rather co-extensive with one's experience, but the fundamental or underlying process will be the same. The concept incongruity may therefore be interpreted with more propriety as the unusual. These unusual coalitions of wit and laughter, however, may at times be eminently fitting or congruous. 
The laughter induced by nitrogen monoxide or by cannabis indica is probably hyperæmic or congestive in its origin. The Rausch in all its forms, æsthetical, political, religious, spirituous, etc., ought also to be treated in this connection. Some psychologist with Atwater courage and with no reputation to lose ought to make a study of the possible individual and social utility of the Rausch. The savages, it is well known, induced this intoxication by various means.

Walter E. Roth, in describing certain songs of the northern Australian aborigines, ${ }^{1}$ relates an interesting fact concerning the genesis of savage emotion. He says that, "while the songs are in progress, one, two or more men - any that like - will take into their mouths, chew and spit out again, the leaves of the 'stinging tree' (Lapartea sp.). What with the pain and irritation so produced, such an individual is speedily aroused into a state bordering on frenzy, when he will commence eating the human excreta prepared for the purpose, will both act and give expression to anything foul and bestial he can think of, do his best to insult everybody present, start chasing the women, and, rushing hither and thither, will finally fall to the ground completely exhausted and collapsed. The mental and physical pain to which the person is thus subjected may be gauged from the fact that it requires some few weeks before he is sufficiently recovered to resume his ordinary routine of daily duties.

A most pernicious doctrine rather prevalent in theories of æsthetics and play is that of self-illusion. One author even goes so far as to say, 'Make-believe, pretence, representation, are of the essence of play, mirth, and art.' It is a case where theory and half-baked analysis run blindly against the facts. The pretence or self-illusion is in the majority of cases quite as illusive as the grin of the Cheshire cat. Sully says 'play is free activity entered upon for its own sake' (p. 146). "Play ceases to be pure play just as soon as the end, for example conquest, begins to be regarded as a thing of consequence to the player" (p. 147). Karl Groos also makes much of this theory, saying, for instance, that 'joy in conquest' is the end of play combats ('Play of Animals,' pp. 291-2).

I do not deny that there are some play-activities into which there enter pretence and make-believe, but it may be remarked at the same time that such plays are very poor play. In studying the phenomena of play two standpoints must be strictly observed, namely, the subjective and the objective. Subjectively the player, if he plays in earn-

1 Walter E. Roth, B.A., M.R.C.S., etc., in Bulletin No. 4, 'North Queensland Ethnography, Games, Sports and Amusements,' Brisbane, March, 1902, p. 22. 
est, that is to say if it is the best type of play, resembles closely in his activity the so-called serious occupations of life. If it were not so it would not be a useful training for after-life. Play is in many ways modeled after social life and is the social life for the child. It is desperately real to him, and he wonders often why adults are living"such a miserable, artificial life, making money and spending wearisome laborious days for ends which are hardly worth the while. The boy who 'monkeys ' or 'fools' at practice games is warned off the field by the coach. No pretence or make-believe is wanted. They play and play to win something outside the play-impulse itself. My psychology students tell me that when they play on the football field all their psychological knowledge about play being a preparation for life drops away from them and they play to win their way to the goal line. It is a serious but withal a joyous occupation to them. Such psychological knowledge may injure to some extent the complete engrossment in these preparatory occupations. The true player drops the word preparatory and simply believes these activities to be serious occupations in which he is tremendously interested. The same is true of plays of a more youthful age. The doll, for the time, is a student in school, is sick, naughty, etc. The tin horse with fore legs longer than the hind legs has longer legs; these crass adults who talk differently are talking of another world of horses. The myths and legends of the child's world are very real worlds to him.

Objectively, of course, we look upon the activities of these early stages of growth as preparatory. To call it a world of pretence is to apply a misnomer and to judge poorly of the value of play. Adults are subject to selection, so also are these preliminary stages, but it ought to be called a propædeutical selection, one by the way not yet recognized by biologists, psychologists or sociologists. ${ }^{1}$

Miss McCracken, in speaking of the poverty-stricken girls of the working classes of a certain city, says very aptly:

"In the first place they have gone to the theatre, and they go to the theatre to see the play; not the players, nor to see how they play the play, nor why they possibly play it thus, nor why they do not play it in some other way (' in any conceivable other way,' as I overheard

${ }^{1}$ A further discassion of this topic will appear shortly under the title of 'Propædeutical Selection.' See also the writer's article on 'Play' in the University of Colorado Studies, Vol. I, No. I, and Mr. H. A. Carr's paper on 'The Survival Values of Play' in the Investigations of the Department of Psychology and Education of the University of Colorado, Vol. I., No. 2.

'Elizabeth McCracken, 'The Play and the Gallery;' Atlantic Monthly, April, 1902 . 
a critic murmur at a recent Shakespearean revival), nor what the author of the play meant, nor what he did not mean, nor what he should have meant. They may see all these things; they frequently do see several of them; but they go to the theatre to see the play. It is interesting to remember that in Shakespeare's time the entire audience went to see the play."

Moreover, the only true criterion of play is the performance of an activity with ease and mastery and with the spirit of pleasure. All else is work or indifferently work or play. If this thesis is granted, then play must not be confined to what we may call traditional forms of play, but must be extended even to adult occupations when performed with the spirit of pleasure and with ease and mastery. For these reasons laughter may be classed as a form of play.

One more point only in this discussion. H. M. Stanley ${ }^{2}$ and Sully ${ }^{3}$ suggest that teasing may well be taken as the starting point in the evolution of play. Taking merely traditional forms of play into account, this $a$ priori statement seems to be hardly warranted by anthropological data. The hypothesis seems to underlie this statement that play is a single impulse, a faculty-of-the-mind affair, whereas it is simply protean in its concrete forms. But leaving this point aside, we can safely lay claim to some actual historical data. Buecher, in his "Arbeit und Rythmus,' ' clearly proves that many songs, dances, and early forms of literature had their origin in the work activities of early men. It is needless here to repeat the evidence adduced to prove the assertion. Then, again, many ancestral adult activities have been modified to suit childish needs; many present-day adult activities are modified in the same way. But farther back than all this we may go and say that play entered in those species in which parental care began to shield their plastic young from the incidence of natural selection. Then propædeutical selection entered, whereby the preliminary, introductory, educative activities and occupations suitable to the particular species in question survived building and moulding for the larger life of the adult. That joy accompanied such a process we can reasonably believe, taking as an analogy the exuberance and fullness of life of youth wherever-we find it.

Arthur Alin.

UNIVERSITY OF CoLORADo.

1 See articles quoted above.

B. M. Stanley, discussion of paper by Hall and Allin on 'Tickling, Laughter, and the Comic, etc.,' PsycholOGICAL REvIEw, 1899, p. 87.

sally, p. I84.

- Followed, and to some extent extended by Gummere, "The Beginnings of Poetry.' 